\title{
Mince from Tilapia-Backbone: Effects of Washing and Cryoprotectant Addition during Frozen Storage
}

\author{
Wendy L. Lizárraga-Mata ${ }^{1}$, Celia O. García-Sifuentes ${ }^{1}$, Susana M. Scheuren-Acevedo ${ }^{1}$, María E. Lugo-Sánchez ${ }^{1}$, \\ Libertad Zamorano-García ${ }^{1}$, Juan C. Ramirez-Suárez ${ }^{1}, \&$ Marcel Martinez-Porchas ${ }^{1}$ \\ ${ }^{1}$ Centro de Investigación en Alimentación y Desarrollo, A. C. Carretera a la Victoria, Km 0.6. Hermosillo, \\ Sonora, C.P. 83304, México \\ Correspondence: Celia Olivia García-Sifuentes, Centro de Investigación en Alimentación y Desarrollo, A. C. \\ Carretera a la Victoria, Km 0.6. Hermosillo, Sonora, C.P. 83304, México. Tel: 52-662-289-2400 (Ext. 511). \\ E-mail: sifuentes@ciad.mx
}

Received: June 10, 2016

Accepted: June 22, 2016 Online Published: August 23, 2016

doi:10.5539/jfr.v5n5p32

URL: http://dx.doi.org/10.5539/jfr.v5n5p32

\begin{abstract}
Mince obtained from tilapia (Oreochromis niloticus) (backbone) was evaluated; the effect of washing and the addition of a commercial cryoprotectant on the quality of the mince obtained were also assessed. Physicochemical, microbiological and sensorial analyses were carried out at 0, 15, 30, 45, 60, 90, 120 and 180 days of frozen storage $\left(-20^{\circ} \mathrm{C}\right)$. During washing treatment $91 \%$ of lipids was removed from the mince $(\mathrm{p}<0.05)$. The proximal composition was stable during the storage time $(p>0.05)$. Parameters such as $L^{*}$ and " $\theta$ " increased while $a^{*}, b^{*}$, chroma and TBARS decreased due to the washing treatment $(p<0.05)$. The cryoprotectant effect resulted in a decrease of $\mathrm{L}^{*}$, " $\theta$ " (Hue) and TBARS $(\mathrm{p}<0.05)$. The addition of the cryoprotectant caused a significant decrease of $L^{*}, " \theta$ " and TBARS. During the storage period, the proximate composition was stable and the microbial load remained below the official limits. The panelists detected changes on the odor, color and texture in the mince evaluated. Results suggest that the washing treatment improved the stability of the mince compared to the addition of cryoprotectant.
\end{abstract}

Keywords: Cryoprotectant, quality, mince, backbone, Oreochromis niloticus, washing, frozen storage

\section{Introduction}

Nile tilapia, Oreochromis niloticus, produces approximately $60-70 \%$ of by-products (skeletons, meat remains, head, skin, bones, scales, and viscera) during the filleting process (Clement \& Lovell, 1994, Abdel-Moemin, 2015). Some of these by-products had been evaluated by developed countries to produce sausages, hamburgers, breaded and other products with fish mince as the main ingredient (Borderías \& Sánchez, 2011; FAO, 2014).

Currently, some of the fish species used for mince production are the Alaska pollock (Theragra chalcogramma), Pacific hake (Merluccius productus), American hake (Merluccius bilinearis) and Argentinian hake (Merluccius bilinearis), rose salmon, cod, catfish, tilapia, mackerel and herring (Alasalvar et al, 2011). However, by-products generated by filleting teleost fish are usually accompanied with blood, pigments, impurities, lipids, enzymes and sarcoplasmic proteins. These components compromise the stability, organoleptic characteristics (taste, texture, appearance, color) and nutritional properties of the mince (Leelapongwattana et al, 2005; Majumdar et al, 2012; Oliveira et al, 2012). Therefore, washing treatments have to be performed. Asgharzadeh, et al (2010), showed that the washing had an important positive effect on carp mince quality, the content of expressible moisture, TVB-N, FFA and thiobarbituric acid reactive substances were decreased. The washing removed fat, pigments, blood, enzymes and water soluble undesirable compounds in carp mince.

Cryoprotectants are compounds widely used to preserve the quality of biological tissues from freezing damage including fishery products (Parvathy et al, 2014; Santya \& Krushna, 2011). These products are required to be nontoxic, cheap and low-molecular weight compounds; herein extracellular agents (do not penetrate cell membranes) improve the osmotic imbalance that occurs during freezing storage, e.g., sucrose, trehalose, and dextrose.

Therefore, the aim of this study was to evaluate the physical and chemical changes of mince obtained from tilapia-skeleton (backbone) as a result of washing and addition of commercial cryoprotectant during frozen storage. 


\section{Materials and Methods}

\subsection{Mince Source and Preparation}

Tilapia backbones (Oreochromis niloticus) were obtained from a local producer who harvested and filleted tilapia in Novillo dam, placed in coolers with ice $\left(0-1^{\circ} \mathrm{C}\right)$ and transported to the laboratory at Research Center of Food and Development in a period no longer than $24 \mathrm{~h}$ after filleting. Upon receipt, backbones were washed with pressurized potable cold water, packed in plastic bags, distributed layered into a cooler (ice-backbones-ice) and stored in a $0-2^{\circ} \mathrm{C}$ chamber for processing. Backbones previously washed and cooled were processed in mechanical deboning equipment (Bibun (NDX103) Bibun Corp. Fakuyama, Japan). The mince obtained was divided and prepared for lots (treatments) as follow:

1) Unwashed mince without cryoprotectant (M). Represent the mince obtained directly from the deboning machine.

2) Unwashed mince with cryoprotectant (MC). Represent the mince obtained directly from the deboning machine with the addition of cryoprotectant mixture, which consisted in $0.1 \%$ of CAFODOS ${ }^{\circ}$ (based in citric acid, sodium citrate and hydrogen peroxide) and $1.0 \%$ of ALTESA® (based in sodium citrate), both diluted in cold drinking water $\left(1^{\circ} \mathrm{C}\right)$ and manually incorporated to the mince.

3) Washed mince without cryoprotectant (MW). Represent the mince obtained from the deboning machine and subjected to two washing steps. Washing was carry out with cold water $\left(0\right.$ to $\left.4^{\circ} \mathrm{C}\right)$ in $1: 3$ (mince/water) proportion, stirred for $2 \mathrm{~min}$ and finally a rest period of $5 \mathrm{~min}$ (Oliveira et al, 2012). During each wash, the floating lipids were manually removed using a strainer. After two washes, the mince was recovered by removing the water with a screw dryer (Bibun, Model SR1000 Bidun Corp., Fakuyama, Japan).

4) Washed mince with cryoprotectant (MWC). Represent the washed mince with the addition of cryoprotectant mixture described previously.

Finally, treatments were packed into vacuum bags in portions of $1 \mathrm{~kg}$ and $4 \mathrm{~cm}$ thick (Prime Source ${ }^{\circledR}$ ), and placed in high density polyethylene shrimp trays $(28 \times 21 \times 5 \mathrm{~cm})$ for freezing. The samples were frozen and stored in a freezer chamber at $-20{ }^{\circ} \mathrm{C}$ for 6 months. Physicochemical, microbiological and sensory evaluations were evaluated on days $0,15,30,45,60,90,120$ and 180 .

\subsection{Physicochemical Analysis}

Proximate analysis of the samples was done in triplicate and was performed by following the A.O.A.C. recommendations (2000). Moisture was assessed by oven drying at $103^{\circ} \mathrm{C}$, while, ash were evaluated at $550^{\circ} \mathrm{C}$ using an electrical muffle furnace (methods 950.46 and 938.08). The crude fat was determined by the Goldfish method (920.39) and the amount of crude protein and non-protein nitrogen was determined by the Micro-Kjeldahl method (A.O.A.C. 960.52). To calculate the protein content the nitrogen factor 6.25 was used.

$\mathrm{pH}$ was monitored by using a potentiometer, following the specifications of Woyewoda et al (1986). Total volatile base nitrogen (TVB-N) was determined by the method of magnesium oxide (Woyewoda et al, 1986) and expressed as $\mathrm{mg}$ of nitrogen per $100 \mathrm{~g}$ of sample.

To evaluate drip loss, two mince blocks $(3.5 \times 2.5 \mathrm{~cm})$ were placed into Ziploc bags and the initial weight was recorded; then they were thawed (CODEX STAN 165-1989) and the water drained during thawing was removed; final weigh was recorded again. Results were reported as percent of weight loss.

Change of color was evaluated by using a Konica Minolta CR-400 (Konica Minolta Sensing, Inc., Tokyo, Japan) colorimeter. Color coordinates were considered to measure the degree of $\mathrm{L}^{*}$ (lightness), $\mathrm{a}^{*}$ (redness or greenness) and $b^{*}$ (yellowness-blueness). The values of $\mathrm{L}^{*}, \mathrm{a}^{*}$ and $\mathrm{b}^{*}$ were used to calculate other color indices such as the hue angle $(\Theta)$, chroma and the total color difference $(\Delta \mathrm{E})$.

The peroxide value was evaluated in lipids extracted from $\mathrm{M}$ and $\mathrm{MW}$, while thiobarbituric acid reactive substances (TBARS) were evaluated directly from samples of M, MW, MC and MWC. Peroxide Value and TBARS were evaluated following the methods described by Woyewoda, Shaw, Ke \& Burns (1986).

\subsection{Microbiological Analysis}

The microbiological analyses were carried out according to the Mexican Official Standards (NOM) and the FDA's Bacteriological Analytical Manual. Total aerobic plates, incubated at $35 \pm 2{ }^{\circ} \mathrm{C}$ and $24 \mathrm{~h}$ (NOM-092-SSA1-1994) and total and fecal coliforms (NOM-112-SSA1-1994) were evaluated. Results were expressed as colony forming units per gram (CFU/g) and most probable number per gram of mince (MPN/g) respectively. 
Bacterial pathogens such as $S$. aureus were evaluated on Baird Parker agar (Difco) at $35-37{ }^{\circ} \mathrm{C}$, Salmonella spp on Xylose Lysine Desoxycholate (XLD) agar (Difco) at 35-37 ${ }^{\circ} \mathrm{C}$ (NOM-114-SSA1-1994 and BAM 2014). Listeria monocytogenes enrichment was performed in UVM Modified Listeria Enrichment Broth (Difco), followed by plating on Oxford (MOX) agar (Difco) incubated at $30^{\circ} \mathrm{C} / 18-24 \mathrm{~h}$ (NOM-143-SSA1-1995 and BAM 2011). Pathogen evaluation was performed at the beginning and the end of the storage time.

\subsection{Sensory Analysis}

For sensory evaluation, the sample was prepared by following the method described in CODEX STAN 165-1989, which consists of placing mince blocks (inside a plastic bag) in a water bath at $21 \pm 1.5{ }^{\circ} \mathrm{C}$ until thawing. Thereafter, the sensory evaluation was conducted by a group of 8 semi-trained panelists. Panelists (males, females, free of allergies and 40-50 years old) received six training sessions to permit the assessment of this study and recommended NMX-F-529-2004 standard was taken as a reference. Furthermore, the panelists have five years of experience in sensory evaluation of fishery products. Changes (odor, color and texture) were evaluated through the storage by using a 16-point scale (NMX-F-529-2004), where: $0=$ no change (characteristic attributes of the sample) and 16= extreme changes (changes due to contamination or decomposition).

\subsection{Statistical Analysis}

A complete randomized design was used with a $2 \times 2 \times 8$ factorial arrangement, where the factors were $\mathrm{X} 1$ (washing treatment), X2 (cryoprotectant treatment) with two levels (with and without) and X3 Storage time (180 days) under frozen conditions with eight sampling dates. Data were analyzed by an analysis of variance for general linear models (GLM). When a significant effect of factors was found, the Tukey-Kramer comparison test was performed with a 5\% significance level using the NCSS statistical software (2007).

\section{Results and Discussion}

\subsection{Physicochemical}

The moisture values obtained in this study are in accordance with the moisture range previously reported for tilapia muscle mince 70-80\% (Biscalchin-Grÿchek et al , 2003). MC moisture was higher than $\mathrm{M}$ because the cryoprotectant added to the mince was diluted in water. There was a $16 \%$ increase (average) in moisture content attributable to the washing treatment (Table 1) and $1.9 \%$ due to the cryoprotectant effect $(\mathrm{p}<0.05)$.

The increase in moisture content after washing (MW and MWC) could be associated to the removal of sarcoplasmic proteins. This change could promote the increment of myofibrillar proteins and finally as a result of these changes, the water retention capacity was increased (Biscalchin-Grÿchek et al , 2003). However, the moisture content $\mathrm{M}(71.3 \%)$ was lower than that reported in other mince species; for instance, $77.1 \%$ was documented in mackerel muscle mince (Eymard et al, 2009), 78.7\% in muscle mince carp (Majumdar et al, 2012), and 81.3 and 78.3\% in tilapia mince backbones (Oliveira et al, 2012; Kirschnik et al, 2013).

No significant difference $(\mathrm{P}>0.05)$ was detected in the tilapia mince moisture content during the 6 month of frozen storage. According to Biscalchin-Gröchek et al (2003) tilapia is considered as high protein source $(15-20 \%)$; however, after the washing process the content of crude protein decreased $(\mathrm{p}<0.05) 25.8 \%$ (calculated under higher water content). If the content of protein in MW is adjusted to the moisture of M (71.3\%) the content of protein in MW decrease as describe previously. The wash-cryoprotectant interaction was not significant for protein content $(\mathrm{p}>0.05)$, but was affected by storage time $(\mathrm{p}<0.05)$. The decrease in the protein content reported in the present study was $13 \%$ lower than that reported for tilapia mince (Oliveira et al, 2012) and $12 \%$ lower than carp muscle mince (Yongsawatdigul et al, 2013).

The decrease in protein content could be associated to the removal of sarcoplasmic- as well as myofibrillar-proteins, but the later in less proportion (Eymard et al, 2009; Yongsawatdigul et al, 2013).

The percentage of lipids removed as a result of the washing treatment was $28 \%$ higher than that reported for other Tilapia-skeleton mince (Oliveira et al, 2012) and $11 \%$ than carp muscle mince (Yongsawatdigul et al, 2013) but, lower (31-37\%) than tilapia muscle mince (Biscalchin-Grÿschek et al, 2003).

The washing process resulted in the removing of $91 \%$ of lipids $(\mathrm{p}<0.05)$ for MW and MWC, while the cryoprotectant addition resulted in $0.8 \%(\mathrm{p}<0.05)$. The wash-cryoprotectant interaction was significant (Table 1). Significant differences for lipid content were detected comparing washed vs non-washed minces $(\mathrm{p}<0.05)$, but no differences were registered between MW and MWC ( $p>0.05)$.

Regarding ash content (Table 1) the registered value in $\mathrm{M}$ was $0.7 \pm 0.2$ which is comparable to previous reports for tilapia-skeleton mince (0.9-1.1\%) (Oliveira et al, 2012; Kirschnik et al, 2013). However, 70\% of the ash content $(\mathrm{p}<0.05)$ was removed through the washing process, which is considerably higher than the removal 
achieved (29-40\%) by other authors for Tilapia-skeleton mince (Oliveira et al, 2012; Kirschnik et al, 2013). The addition of cryoprotectant in the mince caused an ash level enhancement of $10 \%(\mathrm{p}<0.05)$; possibly due to the presence of citric acid and sodium citrate in the cryoprotectant used. Hoke et al. (2000) observed increases of 4\% in the ash content in muscle mince with the addition of sodium citrate. Wash-cryoprotectant interaction had no effect on the percentage of mince ash $(p>0.05)$ and no changes were observed during frozen storage $(p>0.05)$.

Table 1. Chemical composition of tilapia minces during frozen storage.

\begin{tabular}{|c|c|c|c|c|c|c|c|}
\hline \multirow{2}{*}{ Treatment } & \multirow{2}{*}{$\begin{array}{c}\text { Component } \\
(\%)\end{array}$} & & \multicolumn{5}{|c|}{ Storage time (days) } \\
\hline & & $\mathbf{0}$ & 15 & 30 & 45 & 90 & 180 \\
\hline \multirow[t]{5}{*}{$\mathbf{M}$} & Moisture & $\mathrm{A} 71.3 \pm 1.6$ & $73.6 \pm 1.7$ & $72.3 \pm 2.0$ & $73.9 \pm 0.7$ & $74.3 \pm 2.3$ & $72.4 \pm 1.6$ \\
\hline & Lipids & ${ }^{\mathrm{A}} 15.3 \pm 0.7$ & $14.3 \pm 0.5$ & $14.4 \pm 0.5$ & $14.0 \pm 0.7$ & $14.2 \pm 0.6$ & $14.8 \pm 0.6$ \\
\hline & Protein & ${ }^{\mathrm{A}} 12.0 \pm 0.2^{\mathrm{ac}}$ & $10.2 \pm 0.4^{\mathrm{b}}$ & $10.5 \pm 0.1^{\mathrm{bc}}$ & $10.4 \pm 0.8^{\mathrm{bc}}$ & $11.3 \pm 0.3^{\mathrm{c}}$ & $11.8 \pm 0.5^{\mathrm{ac}}$ \\
\hline & Ash & ${ }^{\mathrm{A}} 0.7 \pm 0.2$ & $0.6 \pm 0.1$ & $0.7 \pm 0.1$ & $0.6 \pm 0.0$ & $0.6 \pm 0.1$ & $0.7 \pm 0.0$ \\
\hline & NPN & ${ }^{\mathrm{A}} 0.1 \pm 0.0$ & $0.1 \pm 0.0$ & $0.1 \pm 0.0$ & n.d. & n.d. & $0.0 \pm 0.0$ \\
\hline \multirow[t]{5}{*}{ MC } & Moisture & ${ }^{\mathrm{B}} 76.3 \pm 3.5$ & $75.0 \pm 1.3$ & $75.1 \pm 2.0$ & $75.4 \pm 1.9$ & $74.8 \pm 1.5$ & $75.7 \pm 0.9$ \\
\hline & Lipids & ${ }^{\mathrm{B}} 12.4 \pm 1.4$ & $13.6 \pm 1.3$ & $13.3 \pm 0.8$ & $13.0 \pm 0.7$ & $13.5 \pm 1.2$ & $13.1 \pm 0.7$ \\
\hline & Protein & ${ }^{\mathrm{B}} 10.5 \pm 1.0^{\mathrm{a}}$ & $10.2 \pm 0.6^{\mathrm{a}}$ & $9.9 \pm 0.1^{\mathrm{a}}$ & $8.2 \pm 0.5^{\mathrm{b}}$ & $11.2 \pm 0.6^{\mathrm{a}}$ & $10.5 \pm 0.8^{\mathrm{a}}$ \\
\hline & Ash & ${ }^{\mathrm{A}} 0.6 \pm 0.2$ & $0.7 \pm 0.1$ & $0.6 \pm 0.0$ & $0.7 \pm 0.1$ & $0.7 \pm 0.0$ & $0.7 \pm 0.0$ \\
\hline & NPN & ${ }^{\mathrm{B}} 0.0 \pm 0.0$ & $0.1 \pm 0.0$ & $0.1 \pm 0.0$ & n.d. & n.d. & $0.0 \pm 0.0$ \\
\hline \multirow[t]{5}{*}{ MW } & Moisture & ${ }^{\mathrm{C}} 89.5 \pm 0.1$ & $89.6 \pm 0.2$ & $89.4 \pm 0.6$ & $89.8 \pm 0.3$ & $89.4 \pm 0.9$ & $89.4 \pm 0.5$ \\
\hline & Lipids & ${ }^{\mathrm{B}} 1.4 \pm 0.2$ & $1.2 \pm 0.1$ & $1.5 \pm 0.2$ & $1.3 \pm 0.1$ & $1.4 \pm 0.3$ & $1.4 \pm 0.1$ \\
\hline & Protein & ${ }^{\mathrm{C}} 8.9 \pm 0.3^{\mathrm{ac}}$ & $7.6 \pm 0.1^{b}$ & $7.6 \pm 0.4^{b}$ & $7.8 \pm 0.5^{b}$ & $8.7 \pm 0.2^{\mathrm{a}}$ & $9.5 \pm 0.4^{\mathrm{c}}$ \\
\hline & Ash & ${ }^{\mathrm{B}} 0.2 \pm 0.1$ & $0.2 \pm 0.0$ & $0.2 \pm 0.1$ & $0.2 \pm 0.0$ & $0.2 \pm 0.0$ & $0.2 \pm 0.0$ \\
\hline & NPN & ${ }^{\mathrm{B}} 0.0 \pm 0.0$ & $0.0 \pm 0.0$ & $0.0 \pm 0.0$ & n.d. & n.d. & $0.0 \pm 0.0$ \\
\hline \multirow[t]{5}{*}{ MWC } & Moisture & ${ }^{c_{9}} 90.6 \pm 0.7$ & $90.9 \pm 0.1$ & $90.9 \pm 0.8$ & $90.9 \pm 0.8$ & $90.9 \pm 0.7$ & $91.2 \pm 0.7$ \\
\hline & Lipids & ${ }^{\mathrm{B}} 1.3 \pm 0.1$ & $1.3 \pm 0.4$ & $1.2 \pm 0.2$ & $1.2 \pm 0.1$ & $1.2 \pm 0.1$ & $1.1 \pm 0.2$ \\
\hline & Protein & ${ }^{\mathrm{c}} 8.7 \pm 0.7^{\mathrm{a}}$ & $6.5 \pm 0.5^{\mathrm{b}}$ & $6.6 \pm 0.3^{b}$ & $6.5 \pm 0.5^{\mathrm{b}}$ & $7.9 \pm 0.7^{\mathrm{a}}$ & $7.7 \pm 0.8^{\mathrm{a}}$ \\
\hline & Ash & ${ }^{\mathrm{B}} 0.2 \pm 0.0$ & $0.2 \pm 0.1$ & $0.2 \pm 0.0$ & $0.2 \pm 0.0$ & $0.2 \pm 0.0$ & $0.2 \pm 0.0$ \\
\hline & NPN & ${ }^{\mathrm{B}} 0.0 \pm 0.0$ & $0.0 \pm 0.0$ & $0.0 \pm 0.0$ & n.d. & n.d. & $0.0 \pm 0.0$ \\
\hline
\end{tabular}

Values represent the mean $(n=16) \pm$ standard deviation. Means with different capital letters in the same column indicate the effect of treatments and means with different little case letters in the same row were significantly different $(\mathrm{p}<0.05)$. n.d. $=$ no determined. NPN: Non-protein nitrogen. $\mathrm{M}=$ unwashed mince and non-cryoprotectant. $\mathrm{MC}=$ unwashed mince with cryoprotectant. $\mathrm{MW}=$ washed mince non-cryoprotectant. $\mathrm{MWC}=$ washed mince with cryoprotectant.

Drip loss was also detected in samples; herein, drip loss ranged from 7.2 to $7.9 \%$ in all treatments except for MW which recorded the lowest value $(0.9 \pm 0.4 \%)$. Drip loss of $\mathrm{M}$ was $1.2 \%$ higher than that reported for tilapia muscle mince and $0.8 \%$ lower than other tilapia-skeleton mince (Biscalchin-Gr̈̈chek et al., 20 03; Kirschnik et al., 2012).

During the six months of storage changes in drip loss were also detected (Figure 1). Drip loss in M increased by $5 \%$ at $15^{\text {th }}$ day, while an increase of $0.9 \%$ was detected for MW at the end of the storing period $(\mathrm{p}<0.05)$. No differences were detected $(\mathrm{p}>0.05)$ for MW and MWC, probably due to the presence of the cryoprotectant.

No studies regarding color attributes have been reported by the scientific community for tilapia-skeleton mince during frozen storage. Analysis of variance (GLM) suggest that the mince brightness ( $\mathrm{L}^{*}$ ) increased in average 8.6 units $(\mathrm{p}<0.05)$ as a result of the washing effect (Table 2$)$, but decreased 0.7 units due to the cryoprotectant effect. Hoke et al. (2000) reported an increase of 5 units on the $\mathrm{L}^{*}$ parameter for catfish-skeleton mince, caused by the removal of blood and pigments during the washing process. Furthermore, hydrogen peroxide could be used in some cases to improve color attributes that are important to define the selling price and consumer acceptance. The cryoprotectant mixture used in this study, contains hydrogen peroxide as part of its formulation; however, L* was no improved; Himonides et al. (1999) used hydrogen peroxide as a bleacher in cod mince and found no significant differences for " $L$ " values.

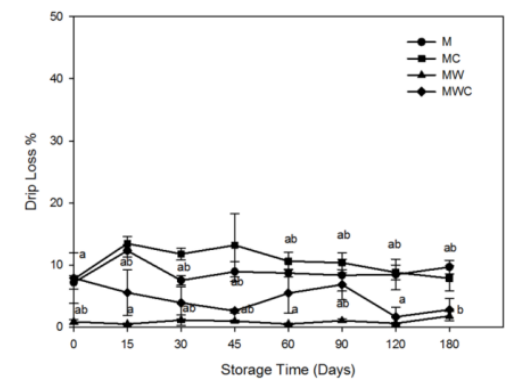

Figure 1. Changes in drip loss of tilapia mince during frozen storage. 
Values represent the mean $(\mathrm{n}=4) \pm$ standard deviation. Means with different letters were significantly different ( $\mathrm{p}$ $<0.05) . \mathrm{M}=$ unwashed mince without cryoprotectant. $\mathrm{MC}=$ unwashed mince with cryoprotectant. $\mathrm{MW}=$ washed mince without cryoprotectant. MWC $=$ washed mince with cryoprotectant.

Results of this study indicated no significant interaction of washing process and cryoprotectant addition ( $p>0.05$ ). Results revealed that during storage time, $\mathrm{L}^{*}$ value increased by 5, 2.2 and 5.5 units in MW, M and MWC respectively $(\mathrm{p}<0.05)$, at $45^{\text {th }}, 60^{\text {th }}$ and $60^{\text {th }}$ days of storing. Herein, Chow et al $(2009)$, concluded that the increase in $\mathrm{L}^{*}$ could be caused by the alkaline $\mathrm{pH}$ of the cryoprotectant used. However, as described previously our results showed an increment in $\mathrm{L}^{*}$ value due to the washing treatment. Similar to $\mathrm{M}$ in this study, Pivarnik et al. (2013) observed no changes in $\mathrm{L}^{*}$ values of tilapia fillets stored at $5^{\circ} \mathrm{C}$ during the frozen storage.

For the red-green values ( $\mathrm{a}^{*}$, Table 2), a decrease of 9.4 units were detected as a result of washing treatment ( $\mathrm{p}<$ $0.05)$. The lower values obtained on $\mathrm{a}^{*}$ were probably the associated to the removal of soluble pigments. Myoglobin, hemoglobin, carotenoid and melanin are the main pigments that contribute to fish color (Thiansilakul et al, 2012); herein, Yarnpakdee et al (2012) documented a myoglobin removal of 52\% in Tilapia-muscle mince after a washing process.

Table 2. Changes in color of tilapia mince during frozen storage.

\begin{tabular}{|c|c|c|c|c|c|c|c|c|c|}
\hline Treatments & $\begin{array}{l}\text { Color } \\
\text { Traits }\end{array}$ & & & & $\begin{array}{l}\text { Storage Time } \\
\text { (Days) }\end{array}$ & & & & \\
\hline & & $\mathbf{0}$ & 15 & 30 & 45 & 60 & 90 & 120 & 180 \\
\hline \multirow[t]{3}{*}{ M } & $\mathbf{L}^{*}$ & ${ }^{\mathrm{A}} 40.07 \pm 4.0$ & $38.34 \pm 2.5$ & $39.76 \pm 2.0$ & $38.43 \pm 1.6$ & $39.88 \pm 2.9$ & $40.21 \pm 2.6$ & $39.69 \pm 2.9$ & $38.91 \pm 3.6$ \\
\hline & $a^{*}$ & ${ }^{A} 8.38+1.1^{\mathrm{a}}$ & $9.70+22^{\text {ab }}$ & $11.14+16^{\mathrm{bc}}$ & $12.00+1.2^{\mathrm{c}}$ & $10.49 \pm 15^{\mathrm{bc}}$ & $10.17 \pm 1.3^{\mathrm{b}}$ & $9.98+16^{\mathrm{ab}}$ & $10.21+22^{\mathrm{bc}}$ \\
\hline & b* & ${ }^{\mathrm{A}} 5.65 \pm 0.9^{\mathrm{a}}$ & $6.07 \pm 1.1^{\text {ac }}$ & $7.38 \pm 0.8^{\mathrm{b}}$ & $7.19 \pm 0.5^{\mathrm{b}}$ & $7.12 \pm 0.8^{\mathrm{b}}$ & $7.12 \pm 0.7^{b}$ & $6.86 \pm 0.9^{\mathrm{bc}}$ & $7.03 \pm 0.7^{\mathrm{b}}$ \\
\hline \multirow[t]{3}{*}{ MW } & $\mathbf{L}^{*}$ & $\mathrm{c}_{43.56 \pm 3.7^{\mathrm{ac}}}$ & $43.61 \pm 6.5^{\text {ac }}$ & $49.46 \pm 3.6^{\mathrm{bc}}$ & $50.64 \pm 3.2^{\mathrm{b}}$ & $51.62 \pm 2.6^{\mathrm{b}}$ & $50.39 \pm 3.6^{\mathrm{b}}$ & $52.03 \pm 2.6^{\mathrm{b}}$ & $46.16 \pm 1.7^{\mathrm{c}}$ \\
\hline & $\mathbf{a}^{*}$ & $\mathrm{c}_{1} 1.56 \pm 1.0^{\mathrm{ac}}$ & $1.47 \pm 0.6^{\mathrm{a}}$ & $0.74 \pm 0.4^{\mathrm{b}}$ & $0.62 \pm 0.3^{\text {bc }}$ & $0.35 \pm 0.2^{\mathrm{ab}}$ & $0.12 \pm 0.2^{\mathrm{b}}$ & $0.33 \pm 0.3^{\mathrm{b}}$ & $0.27 \pm 0.2^{\mathrm{b}}$ \\
\hline & b* & 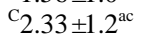 & $3.45 \pm 1.4^{\mathrm{ab}}$ & $2.63 \pm 1.0^{\mathrm{abc}}$ & $3.47 \pm 1.4^{\mathrm{ab}}$ & $3.8 \pm 1.2^{\mathrm{bc}}$ & $3.56 \pm 1.0^{\mathrm{b}}$ & $2.82 \pm 0.8^{\mathrm{abc}}$ & $1.63 \pm 0.6^{\mathrm{ac}}$ \\
\hline \multirow[t]{3}{*}{ MC } & $\mathbf{L}^{*}$ & ${ }^{\mathrm{B}} 38.96 \pm 2.6^{\mathrm{ab}}$ & $37.45 \pm 2.1^{\mathrm{a}}$ & $39.32 \pm 2.4^{\mathrm{ab}}$ & $38.76 \pm 2.7^{\mathrm{ab}}$ & $41.19 \pm 3.1^{b}$ & $40.16 \pm 2.3^{\mathrm{ab}}$ & $38.38 \pm 2.6^{\mathrm{ab}}$ & $38.68 \pm 2.6^{\mathrm{ab}}$ \\
\hline & $a^{*}$ & ${ }^{\mathrm{B}} 10.15 \pm 1.9^{\mathrm{ab}}$ & $11.66+19^{\mathrm{ab}}$ & $11.69+22^{\mathrm{ac}}$ & $11.90+1.9^{\mathrm{a}}$ & $11.02+18^{\mathrm{ab}}$ & $10.53+1.5^{\mathrm{ab}}$ & $9.73+1.6^{\text {bc }}$ & $9.64+2.0^{\mathrm{bc}}$ \\
\hline & b* $^{*}$ & ${ }^{\mathrm{B}} 6.38 \pm 1.0^{\mathrm{a}}$ & $6.74 \pm 0.7^{\text {ad }}$ & $7.67 \pm 0.8^{\mathrm{bc}}$ & $7.82 \pm 0.6^{b c}$ & $8.08 \pm 0.6^{\mathrm{b}}$ & $7.91 \pm 0.4^{\mathrm{bc}}$ & $7.15 \pm 0.5^{\mathrm{cd}}$ & $7.20 \pm 0.7^{\text {cd }}$ \\
\hline \multirow[t]{3}{*}{ MWC } & $\mathbf{L}^{*}$ & $\mathrm{D} 45.42 \pm 4.1^{\mathrm{ad}}$ & $45.48 \pm 2.5^{\mathrm{ad}}$ & $47.67 \pm 3.8^{\mathrm{abc}}$ & $47.2 \pm 3.4^{\text {abd }}$ & $48.94 \pm 2.4^{\mathrm{bc}}$ & $50.88 \pm 3.5^{\mathrm{b}}$ & $49.31 \pm 2.1^{\mathrm{bc}}$ & $44.10 \pm 2.2^{\mathrm{d}}$ \\
\hline & $\mathbf{a}^{*}$ & ${ }^{\mathrm{D}} 0.54 \pm 0.3^{\mathrm{ab}}$ & $0.81 \pm 0.3^{\mathrm{a}}$ & $0.63 \pm 0.4^{\mathrm{ab}}$ & $0.58 \pm 0.3^{\mathrm{ab}}$ & $0.51 \pm 0.2^{\mathrm{bc}}$ & $0.34 \pm 0.3^{\mathrm{c}}$ & $0.35 \pm 0.3^{\mathrm{bc}}$ & $0.40 \pm 0.2^{\mathrm{bc}}$ \\
\hline & b* $^{*}$ & ${ }^{\mathrm{D}} 1.25 \pm 0.8^{\mathrm{a}}$ & $1.32 \pm 0.8^{\mathrm{a}}$ & $2.36 \pm 1.1^{\mathrm{bc}}$ & $2.24 \pm 0.9^{\mathrm{ab}}$ & $2.93 \pm 1.0^{\mathrm{b}}$ & $3.03 \pm 1.1^{\mathrm{b}}$ & $2.04 \pm 0.6^{\mathrm{ab}}$ & $1.76 \pm 1.0^{\mathrm{c}}$ \\
\hline
\end{tabular}

Values represent the mean \pm standard deviation. Means with different capital letters in the same column indicate the effect of treatments and means with different little case letters in the same row were significantly different (p < 0.05). $\mathrm{M}=$ unwashed mince without cryoprotectant. $\mathrm{MC}=$ unwashed mince with cryoprotectant. $\mathrm{MW}=$ washed mince without cryoprotectant. MWC $=$ washed mince with cryoprotectant.

Regarding the use of the cryoprotectant no significant effect of this practice was detected on the $a^{*}$ value $(p>$ $0.05)$, neither significant interactions with the washing factor ( $\mathrm{p}<0.05)$. Finally, $\mathrm{M}$ and MW increased 2.8 and 0.8 $a^{*}$ units $(p<0.05)$ at $30^{\text {th }}$ day of storing, while treatments with cryoprotectant $(M C$ and MWC) did not differ during storage and remained stable during the six months of storage.

With regard to yellow-blue parameter ( $b^{*}$, Table 2), results of analysis of variance (GLM) showed a decrease in average of 4.6 units in the washed mince $(\mathrm{p}<0.05)$; similar results were found in previous reports for washed carp-skeleton mince, where $b^{*}$ decreased 4 units (Suvanich et al, 2000). The cryoprotectant treatment had not a significant effect on this parameter $(\mathrm{p}>0.05)$, but the washing-cryoprotectant interaction was significant $(\mathrm{p}<$ 0.05 ). At $30^{\text {th }}$ day of storage, $b^{*}$ increased $1.7,1.3$ and 1.1 units for M, MWC and MC, respectively ( $<0.05$ ). The increase of $\mathrm{b}^{*}$ in tilapia mince could promote the browning flesh bloodline development due to the oxidation of heme-proteins and the subsequent reduction of a* values (Pivarnik et al., 2013).

Chroma values decreases after the washing process also (Table 3). Mince red saturation decreased 9.7 units as a result of washing $(p<0.05)$, but no significant effect was detected by the addition of cryoprotectant $(p>0.05)$; however, a significant wash-cryoprotectant interaction was recorded $(\mathrm{p}<0.05)$.

The values of hue angle are shown on Table 3, no significant changes were observed for $M$ during the 180 days of storage ( $p>0.05)$. For MC the hue angle increased 4.3 units $\left(60^{\text {th }}\right.$ day), MW increased 8.2 units $\left(15^{\text {th }}\right.$ day) and 7.2 units in MWC after $30^{\text {th }}$ day $(\mathrm{p}<0.05)$, and remained stable for the rest of the storage period. Even though there were a visible color change after washing, $\Delta \mathrm{E}$ was not affected until $30^{\text {th }}$ day $\mathrm{in} \mathrm{M}, 30^{\text {th }}$ and $180^{\text {th }}$ day in $\mathrm{MW}, 60^{\text {th }}$ day in MC and $180^{\text {th }}$ day in MWC (Table 3). In consonance with $\Delta \mathrm{E}$ results, color tones for washed samples end up yellowish, probably associated to $b^{*}$ changes. Unwashed samples (M, MC) were more susceptible to oxidation and discoloration turning brownish-dark pink probably due to presence of oxidized heme-pigments (Suvanish et al, 2000). Chaijan et al (2005) observed a decrease in chroma values of sardine mince due to pigment removal during washing. The color was seen reddish in the $\mathrm{M}$ and $\mathrm{MC}$ at the beginning of 
the storage time and became yellow-green at the end of the trial. Moreover, the MW and MWC had a pink-cream color at the beginning of the storage time, and a yellow-cream color at the end of the storage period.

Table 3. Changes in calculated color traits of tilapia mince during frozen storage.

\begin{tabular}{|c|c|c|c|c|c|c|c|c|c|}
\hline \multirow[t]{2}{*}{ Treatments } & \multirow{2}{*}{$\begin{array}{l}\text { Color } \\
\text { traits }\end{array}$} & \multicolumn{8}{|c|}{ Storage Time (Days) } \\
\hline & & $\mathbf{0}$ & 15 & 30 & 45 & 60 & 90 & 120 & 180 \\
\hline \multirow[t]{3}{*}{$\mathbf{M}$} & $\overline{\boldsymbol{\theta}}$ & ${ }^{\mathrm{A}} 34.03 \pm 5.2$ & $32.40 \pm 3.8$ & $33.76 \pm 3.4$ & $31.01 \pm 2.4$ & $34.33 \pm 3.1$ & $35.21 \pm 4.0$ & $34.65 \pm 2.3$ & $35.26 \pm 6.1$ \\
\hline & Chroma & ${ }^{\mathrm{A}} 10.14 \pm 1.1^{\text {ac }}$ & $9.29 \pm 4.4^{\mathrm{a}}$ & $13.38 \pm 1.6^{\mathrm{b}}$ & $14.00 \pm 1.1^{\mathrm{b}}$ & $12.69 \pm 1.6^{\mathrm{b}}$ & $12.43 \pm 1.2^{\mathrm{b}}$ & $12.12 \pm 1.8^{\mathrm{ab}}$ & $12.45 \pm 2.0^{\mathrm{ab}}$ \\
\hline & $\Delta \mathbf{E}$ & & 2.2 & 2.4 & 1.6 & 2.1 & 0.5 & 0.61 & 0.8 \\
\hline \multirow[t]{3}{*}{ MW } & $\boldsymbol{\theta}$ & ${ }^{\mathrm{B}} 58.45 \pm 9.8^{\mathrm{a}}$ & $66.64 \pm 4.8^{\mathrm{b}}$ & $73.23 \pm 6.5^{\mathrm{bc}}$ & $78.05 \pm 8.1^{\mathrm{cd}}$ & $84.96 \pm 1.8^{\text {de }}$ & $88.02 \pm 2.5^{\mathrm{e}}$ & $83.10 \pm 7.7^{\text {de }}$ & $80.34 \pm 6.0^{\text {cd }}$ \\
\hline & Chroma & ${ }^{\mathrm{C}} 2.84 \pm 1.5^{\mathrm{ab}}$ & $3.76 \pm 1.5^{\mathrm{a}}$ & $2.75 \pm 1.1^{\mathrm{ab}}$ & $3.55 \pm 1.3^{\mathrm{a}}$ & $3.82 \pm 1.2^{\mathrm{a}}$ & $3.56 \pm 1.0^{\mathrm{a}}$ & $2.86 \pm 0.8^{\mathrm{ab}}$ & $1.67 \pm 0.6^{\mathrm{ab}}$ \\
\hline & $\Delta \mathbf{E}$ & & 1.1 & 6.0 & 1.4 & 1.1 & 1.3 & 1.8 & 5.99 \\
\hline \multirow[t]{3}{*}{ MC } & $\boldsymbol{\theta}$ & ${ }^{\mathrm{A}} 32.35 \pm 2.8^{\mathrm{a}}$ & $30.23 \pm 2.1^{\mathrm{a}}$ & $33.6 \pm 2.8^{\mathrm{ab}}$ & $33.60 \pm 3.1^{\mathrm{ab}}$ & $36.62 \pm 3.77^{\mathrm{bc}}$ & $37.20 \pm 3.4^{\mathrm{bc}}$ & $36.71 \pm 4.5^{\mathrm{bc}}$ & $37.24 \pm 3.6^{c}$ \\
\hline & Chroma & ${ }^{\mathrm{B}} 12.00 \pm 2.0^{\mathrm{ab}}$ & $10.31 \pm 4.4^{\mathrm{a}}$ & $13.99 \pm 2.2^{\mathrm{b}}$ & $14.26 \pm 1.8^{\mathrm{b}}$ & $13.69 \pm 1.67^{\mathrm{b}}$ & $13.19 \pm 1.4^{\mathrm{b}}$ & $12.11 \pm 1.3^{\mathrm{bc}}$ & $12.06 \pm 2.0^{\mathrm{b}}$ \\
\hline & $\Delta \mathbf{E}$ & & 2.17 & 2.09 & 0.62 & 2.6 & 1.1 & 2.1 & 0.3 \\
\hline \multirow[t]{3}{*}{ MWC } & $\boldsymbol{\theta}$ & ${ }^{\mathrm{c}} 64.97 \pm 9.3^{\mathrm{ab}}$ & $55.43 \pm 15.1^{\mathrm{a}}$ & $74.21 \pm 10.8^{\mathrm{bc}}$ & $74.63 \pm 10.6^{\mathrm{bcd}}$ & $78.99 \pm 5.2^{\mathrm{cd}}$ & $84.97 \pm 5.6^{\mathrm{d}}$ & $80.16 \pm 7.3^{\text {cd }}$ & $74.68 \pm 9.1_{\mathrm{bcd}}$ \\
\hline & Chroma & ${ }^{\mathrm{D}} 1.37 \pm 0.8^{\mathrm{a}}$ & $1.67 \pm 0.7^{\mathrm{ab}}$ & $2.46 \pm 1.1^{\mathrm{bc}}$ & $2.33 \pm 1.0^{\mathrm{abc}}$ & $2.98 \pm 1.0^{\mathrm{c}}$ & $3.06 \pm 1.1^{\mathrm{c}}$ & $2.08 \pm 0.6^{\mathrm{abc}}$ & $1.82 \pm 1.0^{\mathrm{b}}$ \\
\hline & $\Delta \mathbf{E}$ & & 0.3 & 2.4 & 0.49 & 1.87 & 1.95 & 1.86 & 5.22 \\
\hline
\end{tabular}

Values represent the mean \pm standard deviation. Means with different capital letters in the same column indicate the effect of treatments and means with different little case letters in the same row were significantly different (p < 0.05). $\mathrm{M}=$ unwashed mince without cryoprotectant. $\mathrm{MC}=$ unwashed mince with cryoprotectant. $\mathrm{MW}=$ washed mince without cryoprotectant. MWC = washed mince with cryoprotectant.

Regarding $\mathrm{pH}$, the results registered at day 0 , showed an increase of $0.4 \mathrm{pH}$ units after the washing process $(\mathrm{p}<$ $0.05)$, and 0.5 units after the addition of the cryoprotectant $(\mathrm{p}<0.05)$; significant wash-cryoprotectant interaction was also detected ( $\mathrm{p}$ 0.05). Biscalchin-Gröchek et al (2003) observed a gradual increase in $\mathrm{pH}$ on washed tilapia-muscle mince, and argued that this pattern can continue if additional wash cycles are performed. Higher $\mathrm{pH}$ values in washed mince may occur due to the removal of free fatty acids, free amino acids, lactic acid and other water-soluble acidic substances (Majumdar et al, 2012). The initial values of $\mathrm{pH}$ were 7.2, 7.2, 7.4 and 7.7 for M, MW, MC and MWC, respectively. $\mathrm{pH}$ decreased ( $\mathrm{p}<0.05) 0.2$ units at $45^{\text {th }}$ day in $\mathrm{M}, 0.4$ at $120^{\text {th }}$ day in $\mathrm{MC}$ and 0.1 at $90^{\text {th }}$ day in MW; no significant changes were observed for MWC during the storage period.

Significant changes were also detected for TVB-N; a decrease of $61 \%$ was associated the washing effect $(<0.05$, Figure 2 ) and $<10 \%$ to the cryoprotectant addition $(\mathrm{p}<0.05)$. No significant washing-cryoprotectant interaction was detected, but a significant effect of storage period was registered $(\mathrm{p}<0.05)$. All minces reported TVB-N values lower than the official permitted limits ( 30 to $35 \mathrm{mg} \mathrm{N} / 100 \mathrm{~g}$ ). Unlike the present study, previous reports observed an increase of BVT-N content (80\%) in frozen tilapia fillets during storage (Emire \& Gebremariam, 2009 ) and $33 \%$ after the $60^{\text {th }}$ day of tilapia-sketelon mince freezing storage (Kirschnik et al, 2013).

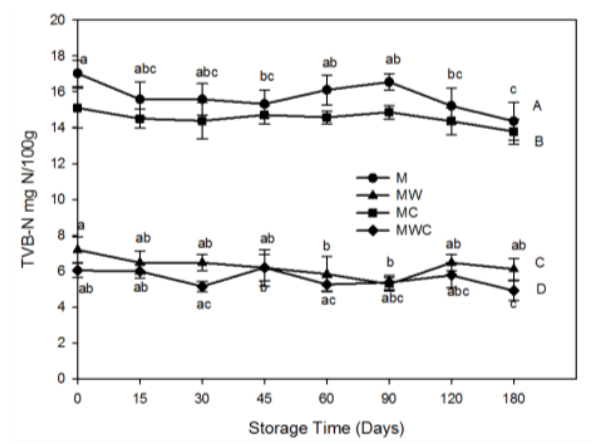

Figure 2. Changes in total volatile bases nitrogen (TVB-N) of tilapia mince during frozen storage.

Values represent the mean $(n=6) \pm$ standard deviation. Means with different capital letters indicates the effect of treatments and little case letters indicates the effect of storage time $(\mathrm{p}<0.05) . \mathrm{M}=$ unwashed mince without cryoprotectant. $\mathrm{MC}=$ unwashed mince with cryoprotectant. $\mathrm{MW}=$ washed mince without cryoprotectant. $\mathrm{MWC}=$ washed mince with cryoprotectant.

Peroxide values for washed mince were not determined due to its low lipid content. The PV values at the beginning of storage were $1.1 \pm 0.5 \mathrm{meq} / \mathrm{kg}$ for $\mathrm{M}$ and $0.7 \pm 0.4 \mathrm{meq} / \mathrm{kg}$ for MC. No effect of the cryoprotectant addition $(p>0.05)$ was observed. Moreover, during frozen storage, no changes were observed for $M(p>0.05)$, but MC increased by $1.0 \mathrm{meq} / \mathrm{kg}$ at $60^{\text {th }}$ day of storage $(\mathrm{p}<0.05)$ (Data not shown). The PV values were 
maintained under the acceptable limits $(\mathrm{MC}=1.1 \pm 0.5 \mathrm{meq} / \mathrm{kg}$ and $\mathrm{M}=0.7 \pm 0.4 \mathrm{meq} / \mathrm{kg})$ compared with normal values suggested for fish 10-20 meq/kg (Sallam, 2007), probably due to the lean characteristic of the mince elaborated in this study.

Thiobarbituric acid reactive substances registered a decrease $(p<0.05)$ of $59 \%$ and $19 \%$ due to the washing and cryoprotectant effect, respectively (Figure 3 ). Mince washing treatment can prevent lipid oxidation because most of the lipid, hydroperoxides and secondary oxidation compounds are removed, providing greater stability to a food product (Fogaca et al., 2015). Furthermore, Kilinc et al (2009), observed a decrease of $20.5 \%$ of TBARS in trout fillets treated with a solution of sodium citrate $2.5 \%$. Citric acid and its salts have been reported to have antioxidant effect when used as a pretreatment to frozen fish storage, acting as synergists, oxygen scavengers and heavy metal chelators (Aubourg et al, 2004; Sanjuás-Rey et al, 2011). Results also indicated that the wash-cryoprotectant interaction was not significant $(\mathrm{p}>0.05)$.

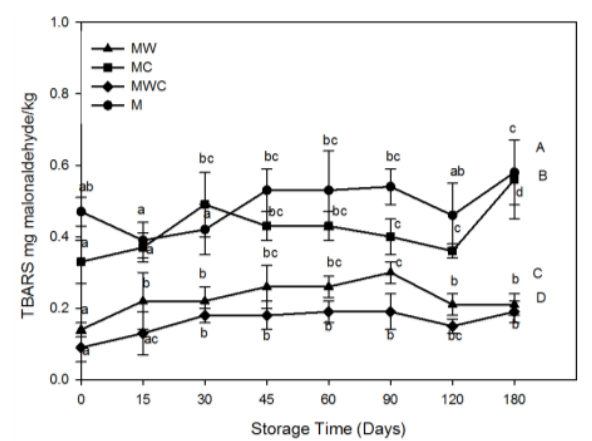

Figure 3. Changes in thiobarbituric acid reactive substances (TBARS) level of tilapia mince during frozen storage.

Values represent the mean $(n=6) \pm$ standard deviation. Means with different capital letters indicates the effect of treatments and little case letters indicates the effect of storage time $(\mathrm{p}<0.05) . \mathrm{M}=$ unwashed mince without cryoprotectant. $\mathrm{MC}=$ unwashed mince with cryoprotectant. $\mathrm{MW}=$ washed mince without cryoprotectant. $\mathrm{MWC}=$ washed mince with cryoprotectant.

An increase $(\mathrm{p}<0.05)$ of TBARS in mince was observed during storage time. MC and MWC increased 0.2 and $0.1 \mathrm{mg}$ malonaldehyde $/ \mathrm{kg}$ respectively at $30^{\text {th }}$ day, whereas MW and $\mathrm{M}$ increased $0.1 \mathrm{mg}$ of malonaldehyde $/ \mathrm{kg}$ at $15^{\text {th }}$ and $45^{\text {th }}$, days respectively. At the end of the storage, all treatments registered TBARS levels below $3 \mathrm{mg}$ of malonaldehyde/kg, which is within the range recommended by Kilinc et al (2009), for human consumption (7-8 $\mathrm{mg}$ of malonaldehyde $/ \mathrm{kg}$ ).

\subsection{Microbiological Analysis}

Microbiological results in unfrozen minces resulted in Mesophiles count of 5.3 $\pm 0.6,5.1 \pm 0.5,4.9 \pm 0.2$ and 4.0 $\pm 0.1 \mathrm{CFU} / \mathrm{g} \log$ for M, MW, MC and MCW, respectively. Total coliforms were 15 $\pm 7,30 \pm 14,150 \pm 32$ and $148 \pm 61$ for M, MW, MC and MCW, respectively. With regards to $S$. aureus all minces registered $<100 \mathrm{CFU} / \mathrm{g}$, whereas Salmonella spp and L. monocytogenes were absent. Unfrozen and frozen minces showed mesophilic counts and total coliforms below the permitted limits $(<7 \mathrm{CFU} / \mathrm{g} \log ,<400 \mathrm{MPN} / \mathrm{g}$, respectively), suggesting a good quality from the microbiological perspective. The absence of pathogenic microorganisms was also confirmed in accordance with international and the mexican standards (NOM-242-SSA1-2009; CODEX STAN 165-1989; ICMSF, 1986).

Analysis of variance (GLM) showed a reduction in average of $0.6 \mathrm{CFU} / \mathrm{g} \log (\mathrm{p}<0.05)$ in mesophilic count (Table 4) and $0.5 \mathrm{CFU} / \mathrm{g}$ log due to the washing and cryoprotectant effect, respectively. During storage, MWC decreased $1.4 \mathrm{CFU} / \mathrm{g} \log (\mathrm{p}<0.05)$, whereas no significant changes were observed in M, MW and MWC treatments $(p>0.05)$. Total mesophiles count demonstrated that after six months of storage, the minces bacterial loads remained under the permitted limits, which can be associated somehow to the washing treatment. 
Table 4. Microbiological evaluation of tilapia minces during frozen storage.

\begin{tabular}{|c|c|c|c|c|c|c|c|c|c|}
\hline \multicolumn{3}{|c|}{ Treatments Microorganism } & \multicolumn{7}{|c|}{ Storage Time (Days) } \\
\hline & & $\mathbf{0}$ & 15 & 30 & 45 & 60 & 90 & 120 & 180 \\
\hline \multirow[t]{2}{*}{$\mathbf{M}$} & Mesophiles & ${ }^{\mathrm{A}} 5.5 \pm 0.6$ & $5.2 \pm 0.4$ & $5.2 \pm 0.3$ & $4.8 \pm 0.1$ & $4.6 \pm 1.5$ & $4.1 \pm 0.5$ & $4.2 \pm 0.6$ & $6.0 \pm 0.01$ \\
\hline & & ${ }^{\mathrm{A}} 80.0 \pm 17.3$ & $150.0 \pm 23.0$ & $126.7 \pm 25.1$ & $172.5 \pm 80.5$ & $135 \pm 51.8$ & $131.5 \pm 125.2$ & $130 \pm 126.4$ & $240 \pm 0.0$ \\
\hline \multirow[t]{2}{*}{ MW } & Mesophiles & $\mathrm{C}_{4.4 \pm 0.7}$ & $4.6 \pm 0.1$ & $4.5 \pm 0.7$ & $3.8 \pm 0.1$ & $3.8 \pm 0.1$ & $4.2 \pm 0.4$ & $3.6 \pm 0.1$ & $4.0 \pm 0.6$ \\
\hline & FC & в $30 \pm 8.2$ & $6.7 \pm 5.9$ & $27.5 \pm 27.5$ & $52.5 \pm 5.0$ & $30 \pm 8.1$ & $11.5 \pm 13.3$ & $48.5 \pm 51.4$ & $50 \pm 49.7$ \\
\hline \multirow[t]{2}{*}{ MC } & Mesophiles & ${ }^{\mathrm{B}} 4.6 \pm 0.4^{\mathrm{ac}}$ & $4.4 \pm 0.2^{\mathrm{ac}}$ & $4.3 \pm 0.4^{\mathrm{abc}}$ & $4.6 \pm 0.0^{\mathrm{ac}}$ & $4.0 \pm 0.6^{\mathrm{ab}}$ & $4.0 \pm 0.3^{\text {abc }}$ & $3.2 \pm 0.6^{\mathrm{b}}$ & $5.1 \pm 0.1^{\mathrm{c}}$ \\
\hline & FC & В $36.7 \pm 11.5$ & $17.5 \pm 15$ & $37.5 \pm 29.9$ & $9 \pm 0.0$ & $12 \pm 3.5$ & $9 \pm 2.3$ & $5.5 \pm 1.7$ & $16.8 \pm 8.08$ \\
\hline \multirow[t]{2}{*}{ MWC } & Mesophiles & ${ }^{\mathrm{D}} 4 \pm 0.1$ & $3.6 \pm 0.1$ & $3.8 \pm 0.3$ & $3.6 \pm 0.1$ & $3.6 \pm 0.0$ & $3.8 \pm 0.1$ & $4.1 \pm 0.7$ & $3.8 \pm 0.3$ \\
\hline & $\mathrm{FC}$ & ${ }^{\mathrm{B}}<3 \pm 0$ & $22.5 \pm 17.08$ & $15 \pm 10$ & $34.5 \pm 9.8$ & $<3 \pm 2.3$ & $<3 \pm 2.3$ & $13 \pm 11.5$ & $5.0 \pm 2.3$ \\
\hline
\end{tabular}

Values represent the mean \pm standard deviation. Means with different capital letters in the same column indicate the effect of treatments and means with different little case letters in the same row were significantly different (p $<0.05) . \mathrm{M}=$ unwashed mince without cryoprotectant. $\mathrm{MC}=$ unwashed mince with cryoprotectant. $\mathrm{MW}=$ washed mince without cryoprotectant. MWC $=$ washed mince with cryoprotectant. Mesophiles are express as Log CFU/g. FC = Fecal Coliform is express as MPN/g.

The fecal coliform count in mince resulted in a reduction of $60 \mathrm{MPN} / \mathrm{g}$ due to the washing effect $(\mathrm{p}<0.05)$ and $74 \mathrm{MPN} / \mathrm{g}$ due to the cryoprotectant addition (Table 4). The limits recommended in fresh and frozen fish for fecal coliforms should be $<230 \mathrm{MPN} / \mathrm{g}$, whereas $E$. coli should be absent (ICMSF, 1986). Lowering the number of sanitary-indicator microorganisms (e.g., coliforms) in food products can be beneficial for assessing effectiveness of safety procedures during processing and handling. Shaviklo \& Rafipour (2013) observed a reduction $82 \mathrm{MPN} / \mathrm{g}$ of fecal coliform during the washing process of myctophid-mince fish to obtain surimi. In contrast, no effect due to washing process was observed on fecal coliform counts of catfish-skeleton mince (Suvanich et al, 2000).

Regarding cryoprotectant effectiveness to decrease bacterial loads, previous studies reported a decrease of 35 MPN/g fecal coliform in trout fillet due to sodium citrate (2.5\%) use (Kilinc et al., 2009). Sanjuás-Rey et al (2012), also observed a decrease of $89 \mathrm{NMP} / \mathrm{g}$ fecal coliforms by the addition of an organic acid solution (citric, ascorbic acid and lactic acid) during mackerel storage. In this way, maybe the organic acids and their salts cross the microbial membranes and come into to the cytoplasm. Inside the cytoplasm, acids dissociate and the microorganisms eliminate the anions excess out of the cytoplasm to protect the physiological $\mathrm{pH}$; however, this process causes limiting of growth or microbial die (Kilinc et al., 2009). Therefore, both wash and cryoprotectant treatments evaluated achieved an effective reduction in fecal coliform counts in tilapia-mince backbones; at day $180^{\text {th }}$ all minces registered bacterial loads below the permitted limits of fecal coliforms (400 MPN/g); thus, no significant changes was observed during the storage for fecal coliforms in all minces. Furthermore, $0 \mathrm{NPN} / \mathrm{g}$ of $E$. coli was registered for all minces along the storage period. Finally, pathogen evaluation on the tilapia mince at $180^{\text {th }}$ day resulted in S. aureus counts $<100 \mathrm{CFU} / \mathrm{g}$ and absence of Salmonella spp and L. monocytogenes.

\subsection{Sensory Analysis}

Features of tilapia-skeleton mince such as low fat content and low lipid oxidation rates (TBARS), contributed to panelists to detect slight odor changes during storage (Table 5). The sensory panel detected slight odor changes on $\mathrm{M}$ after the $120^{\text {th }}$ day of storage ( $<<0.05$ ). In the case of MW slight changes were detected until the end of storage ( $p<0.05)$. In MC and MWC changes in odor occurred after $60^{\text {th }}$ day of storage $(p<0.05)$, suggesting that the cryoprotectant probably promoted a slight but detectable odor by panelists. The reduction in the content of hemoglobin, myoglobin and iron from hemoglobin due to the washing treatment (MW and MWC) increases the stability to lipid oxidation and reduces the formation of volatile (odor producing) compounds (Yarnpakdee et $\mathrm{al}, 2012)$. In MWC and MW, the panel detected slight changes on color at $180^{\text {th }}$ day $(\mathrm{p}<0.05)$ while in MC and $M$ changes were detected after $60^{\text {th }}$ day of storage $(p<0.05)$. Panelists reported that non-washed treatments $(M$ and $\mathrm{MC}$ ) had brown color tones during storage while washing treatments (MW and MWC) after $30^{\text {th }}$ day of storage turned to clearer yellow hues, resulting in yellow-cream color at the end of the storage. Color changes detected by the panelists somehow agree with the results evaluated instrumentally and explained in previous sections. 
Table 5. Sensory evaluation of tilapia minces during the frozen storage.

\begin{tabular}{|c|c|c|c|c|c|}
\hline Parameter & Storage time (days) & M & MW & MC & MWC \\
\hline \multirow{8}{*}{ Color } & 0 & $0.05 \pm 0.08^{\mathrm{a}}$ & $0.13 \pm 0.12^{\mathrm{a}}$ & $0.06 \pm 0.11^{\mathrm{a}}$ & $0.09 \pm 0.14^{\mathrm{a}}$ \\
\hline & 15 & $1.44 \pm 1.48^{\mathrm{ab}}$ & $0.66 \pm 0.74^{\mathrm{a}}$ & $2.10 \pm 2.34^{\mathrm{abc}}$ & $1.48 \pm 1.77^{\mathrm{ab}}$ \\
\hline & 30 & $2.10 \pm 1.93^{\mathrm{ab}}$ & $1.44 \pm 1.36^{\mathrm{a}}$ & $1.81 \pm 1.41^{\mathrm{ab}}$ & $1.60 \pm 1.37^{\mathrm{ab}}$ \\
\hline & 45 & $2.76 \pm 1.57^{\mathrm{abc}}$ & $0.76 \pm 0.40^{\mathrm{a}}$ & $2.81 \pm 2.27^{\mathrm{abc}}$ & $1.16 \pm 0.94^{\mathrm{ab}}$ \\
\hline & 60 & $3.57 \pm 3.18^{\mathrm{bc}}$ & $2.49 \pm 1.73^{\mathrm{ac}}$ & $4.86 \pm 3.16^{\mathrm{bcd}}$ & $1.87 \pm 1.84^{\mathrm{ab}}$ \\
\hline & 90 & $2.30 \pm 1.47^{\mathrm{abc}}$ & $1.33 \pm 1.27^{\mathrm{a}}$ & $2.30 \pm 2.28^{\mathrm{abc}}$ & $1.15 \pm 0.9^{\mathrm{ab}}$ \\
\hline & 120 & $3.76 \pm 2.44^{\mathrm{bc}}$ & $3.98 \pm 2.86^{\mathrm{bc}}$ & $5.30 \pm 4,26^{\mathrm{cd}}$ & $3.35 \pm 2.9^{\mathrm{bc}}$ \\
\hline & 180 & $4.88 \pm 2.98^{\mathrm{c}}$ & $5.43 \pm 3.38^{\mathrm{b}}$ & $6.73 \pm 4.41^{\mathrm{d}}$ & $5.45 \pm 3.39^{\mathrm{c}}$ \\
\hline \multirow[t]{8}{*}{ Odor } & 0 & $0.11 \pm 0.13^{\mathrm{a}}$ & $0.13 \pm 0.12^{\mathrm{a}}$ & $0.07 \pm 0.11^{2}$ & $0.06 \pm 0.09^{\mathrm{a}}$ \\
\hline & 15 & $1.74 \pm 1.72^{\mathrm{ac}}$ & $0.50 \pm 0.58^{\mathrm{a}}$ & $1.42 \pm 1.25^{\mathrm{ab}}$ & $1.61 \pm 1.77^{\mathrm{ab}}$ \\
\hline & 30 & $2.09 \pm 1.76^{\mathrm{ab}}$ & $1.90 \pm 1.82^{\mathrm{ab}}$ & $1.91 \pm 1.48^{\mathrm{abc}}$ & $0.97 \pm 0.85^{\mathrm{ac}}$ \\
\hline & 45 & $2.34 \pm 1.99^{\mathrm{ab}}$ & $1.36 \pm 1.01^{\mathrm{ab}}$ & $3.05 \pm 1.99^{\mathrm{abc}}$ & $2.60 \pm 1.28^{\mathrm{ab}}$ \\
\hline & 60 & $2.58 \pm 2.11^{\mathrm{ab}}$ & $3.73 \pm 3.63^{\mathrm{bc}}$ & $4.83 \pm 4.15^{\mathrm{bcd}}$ & $4.01 \pm 3.79^{\mathrm{bd}}$ \\
\hline & 90 & $2.57 \pm 1.44^{\mathrm{ab}}$ & $3.67 \pm 2.34^{\mathrm{bc}}$ & $3.22 \pm 1.69^{\mathrm{bcd}}$ & $3.27 \pm 2.38^{\mathrm{bcd}}$ \\
\hline & 120 & $4.38 \pm 3.36^{\mathrm{ab}}$ & $2.72 \pm 1.96^{\mathrm{abc}}$ & $5.18 \pm 4.25^{\mathrm{cd}}$ & $3.03 \pm 2.39^{\mathrm{bc}}$ \\
\hline & 180 & $3.90 \pm 1.88^{\mathrm{bc}}$ & $4.87 \pm 3.05^{\mathrm{c}}$ & $6.95 \pm 5.18^{\mathrm{d}}$ & $5.90 \pm 3.64^{\mathrm{d}}$ \\
\hline \multirow[t]{8}{*}{ Texture } & 0 & $0.11 \pm 0.13^{\mathrm{a}}$ & $0.19 \pm 0.12^{\mathrm{a}}$ & $0.07 \pm 0.08^{2}$ & $0.16 \pm 0.26^{\mathrm{a}}$ \\
\hline & 15 & $1.69 \pm 2.23^{\mathrm{a}}$ & $0.28 \pm 0.31^{\mathrm{a}}$ & $0.85 \pm 1.19^{\mathrm{ab}}$ & $0.45 \pm 0.44^{\mathrm{a}}$ \\
\hline & 30 & $1.60 \pm 1.42^{\mathrm{a}}$ & $0.76 \pm 0.78^{\mathrm{a}}$ & $0.98 \pm 0.55^{\mathrm{ab}}$ & $1.23 \pm 0.96^{\mathrm{ab}}$ \\
\hline & 45 & $1.85 \pm 1.78^{\circ}$ & $0.53 \pm 0.53^{\mathrm{a}}$ & $1.69 \pm 1.6^{\mathrm{abc}}$ & $1.29 \pm 1.31^{\mathrm{ab}}$ \\
\hline & 60 & $2.88 \pm 1.87^{\mathrm{ab}}$ & $1.76 \pm 1.3^{\mathrm{ac}}$ & $3.34 \pm 3.14^{\mathrm{abc}}$ & $3.43 \pm 3.41^{\mathrm{bc}}$ \\
\hline & 90 & $1.72 \pm 1.54^{\mathrm{a}}$ & $1.37 \pm 1.33^{\mathrm{ac}}$ & $1.91 \pm 1.99^{\mathrm{abc}}$ & $1.78 \pm 1.9^{\mathrm{abc}}$ \\
\hline & 120 & $1.72 \pm 1.75^{\mathrm{a}}$ & $2.72 \pm 3.4^{\mathrm{bc}}$ & $4.05 \pm 4.9^{\mathrm{bc}}$ & $3.02 \pm 3.08^{\mathrm{bc}}$ \\
\hline & 180 & $5.35 \pm 4.38^{\mathrm{b}}$ & $3.87 \pm 2.19^{\mathrm{b}}$ & $4.77 \pm 4.45^{\mathrm{c}}$ & $4.09 \pm 2.31^{\mathrm{c}}$ \\
\hline
\end{tabular}

Values represent the mean \pm standard deviation. Means with different little case letters in the same row were significantly different $(\mathrm{p}<0.05) . \mathrm{M}=$ unwashed mince without cryoprotectant. $\mathrm{MC}=$ unwashed mince with cryoprotectant. $\mathrm{MW}=$ washed mince without cryoprotectant. $\mathrm{MWC}=$ washed mince with cryoprotectant.

The panel did not detect changes in the texture of MW $(\mathrm{p}>0.05)$. However, MC registered slight textural changes at $120^{\text {th }}$ day of storage, whereas the $\mathrm{M}$ and MWC were at $180^{\text {th }}$ day $(\mathrm{p}<0.05)$. Results showed that $\mathrm{M}$ and $\mathrm{MC}$ presented a soft texture that offered no resistance when it was pressed; in addition samples presented an evident drip loss, whereas MW and MWC had a firmer texture. The textural changes observed were more related with the treatment (washing) and storage condition (freezing). Previous studies suggested that washed carp mince showed higher water holding capacity than non-washed mince, resulting in a firmer mince but although the mince water holding capacity in both cases decreased during frozen storage, the gel forming ability of carp mince was retained for a minimum of 135 days (Majumdar et al, 2012).

\section{Conclusions}

The frozen mince resulted to be safe from the microbiological perspective and had a stable physicochemical and sensorial quality for six months of storage, suggesting that the product may have a longer shelf-life, particularly due to the washing treatment compared to the selected concentrations of the commercial cryoprotectant. Minces obtained from tilapia backbone offered good quality and organoleptic characteristics; therefore, have great potential to develop value-added products.

\section{References}

A. O. A. C. (2000). Official Methods of Analysis of AOAC (Vol II). Washington, D. C., USA: Association of Official Analytical Chemists (Association of official analytical chemists).

Abdel-Moemin, A. R. (2015). Healthy cookies from cooked fish bones. Food Bioscience, 12, 114-12. http://dx.doi.org/10.1016/j.fbio.2015.09.003

Alasalvar, C., Shahidi, F., Miyashita, K., \& Wanasundra, U. (2011). Handbook of seafood quality, safety and health applications. p 576. Wiley-Blackwell. First edition.

Aubourg, S. P., Pérez, F., \& Gallardo, J. M. (2004). Studies on rancidity inhibition in frozen horse mackerel (Trachurus trachurus) by citric and ascorbic acids. European Journal of Lipid Science and Technology, 106(4), 232-240. http://dx.doi.org/10.1002/ejlt.200400937

Asgharzadeh, A., Shabanpour, B., Aubourg, S. P., \& Hosseini, H. (2010). Chemical changes in silver carp (Hypophthalmichthys molitrix) minced muscle during frozen storage: Effect of a previous washing process. Grasas y Aceites, 61(1), 95-101. http://dx.doi.org/10.3989/gya.087109.

Biscalchin-Grÿchek, S. F., Oetterer, M., \& Gallo, C. R. (2003). Characterization and frozen storage stability of minced Nile tilapia (Oreochromis niloticus) and red tilapia (Oreochromis spp.). Journal of Aquatic Food Product Technology, 12(3), 57-69. http://dx.doi.org/10.1300/J030v12n03_06 
Borderías, A. J., \& Sánchez-Alonso I. (2011). First processing steps and the quality of wild and farmed fish. Journal of Food Science, 76(1), R1-R5. http://dx.doi.org/10.1111/j.1750-3841.2010.01900.x

Chaijan, M., Benjakul, S., Visessanguan, W., \& Fautsman, C. (2005). Changes of pigments and color in sardine (Sardinella gibbosa) and mackerel (Rastrelliger kanagurta) muscle during ice storage. Food Chemistry, 93, 607-617. http://dx.doi.org/10.1016/j.foodchem.2004.10.035

Chow, C., Yang, J., Lee, P., \& Ochiai, Y. (2009). Effects of acid and alkaline pretreatment on the discoloration rates of dark muscle and myoglobin extract of skinned tilapia fillet during iced storage. Fisheries Science. 75(6), 1481-1488. http://dx.doi.org/10.1007/s12562-009-0168-z

Clement, S., \& Lovell, R. T. (1994). Comparison of processing yield and nutrient composition of cultured Nile tilapia (Oreochromis niloticus) and channel catfish (Ictalurus punctatus). Aquaculture, 119, 299-310. http://dx.doi.org/10.1016/0044-8486(94)90184-8

CODEX STAN 165-1989. Norma para bloques de filetes de pescado congelados, carne de pescado picada y mezclas de filetes y carne de pescado picada congelados rápidamente. Codex Alimentarius. Normas Internacionales de los Alimentos.

Emire, S. A., \& Gebremariam, M. M. (2009). Influence of frozen period on the proximate composition and microbiological quality of nile tilapia fish (Oreochromis niloticus). Journal of Food Processing and Preservation, 34, 743-757. http://dx.doi.org/10.1111/j.1745-4549.2009.00392.x

Eymard, S., Baron, C. P., \& Jacobcsen, C. (2009). Oxidation of lipid and protein in horse mackerel (Trachurus trachurus) mince and washed minces during processing and storage. Food Chemistry, 114(1), 57-65. http://dx.doi.org/10.1016/j.foodchem.2008.09.030

FAO. (2014). El estado mundial de la pesca y la acuicultura, oportunidades y desafíos. Organización de las Naciones Unidas para la Alimentación y la Agricultura. pp 192-196. Roma.

Fogaca, F. H., Sant, L. S., Ferreir,a J. A., Giacometti, M., \& Carneiro, D. J. (2015). Restructured products from tilapia industry byproducts: The effects of tapioca starch and washing cycles. Food and Bioproducts Processing, 94, 482-488. http://dx.doi.org/10.1016/j.fbp.2014.07.003

Himonides, A. T., Taylor, K. D. A., \& Knowles, M. J. (1999). The improved whitening of cod and haddock flaps using hydrogen peroxide. Journal of the Science of Food and Agriculture. 79(6), 845-850. http://dx.doi.org/10.1002/(SICI)1097-0010(19990501)79:6<845::AID-JSFA297>3.0.CO;2-W

Hoke, M. E., Jahncke, M. L., Silva, J. L., Hearnsberger, J. O., Chamul, R. S., \& Suriyaphan, O. (2000). Stability of washed frozen mince from channel catfish frames. Journal of Food Science, 65(6), 1083-1086. http://dx.doi.org/10.1111/j.1365-2621.2000.tb09422.x/pdf

ICMSF (International Commission of Microbiological Specification for Food). (1986). Sampling for microbiological analysis: Principles and specific applications. Microorganisms in food. International Commission on the Microbiological Specification of Foods. Toronto Press, Toronto, Canada.

Kilinc, B., Cakli, S., Dincer, T., \& Tolasa, S. (2009). Microbiological, chemical, sensory, color and textural changes of rainbow trout fillets treated with sodium acetate, sodium lactate, sodium citrate, and stored at $4^{\circ}$ C. Journal of Aquatic Food Product Technology, 18, 3-17. http://dx.doi.org/10.1080/10498850802580924

Kirschnik, P. G., Trindade, M. A., Gomide, C. A., Gaglianone, M. E., \& Macedo, E. M. (2013). Storage stability of nile tilapia meat mechanically separated, washed, added with preservatives and frozen. Pesquisa Agropecuária Brasileira, 48(8), 935-942. http://dx.doi.org/10.1590/S0100-204X2013000800018

Leelapongwattana, K., Benjakul, S., Visessanguan, W., \& Howell, N. K. (2005). Physicochemical and biochemical changes during frozen storage of mince flesh of lizardfish (Saurida micropectoralis). Food Chemistry, 90, 141-150. http://dx.doi.org/10.1016/j.foodchem.2004.03.038

Majumdar, R. K., Deb, S., Dhar, B., \& Priyadarshini, B. M. (2012). Chemical changes in washed mince of silver carp (Hypophthalmichthys militrix) during frozen storage at $-20^{\circ} \mathrm{C}$ with or without cryoprotectants. Journal of Food Processing and Preservation, 37(5), 952-961. http://dx.doi.org/10.1111/j.1745-4549.2012.00741.x

Meilgaard, M., Civille, G. V., \& Carr, B. T. (1987). Sensory Evalaution Techniques (2nd Ed.). CRC Press, INC. Boca Raton, Florida.

NOM-242-SSA1-2009. Productos y servicios. Productos de la pesca frescos, refrigerados, congelados y procesados. Especificaciones sanitarias y métodos de prueba. 
Oliveira, P. R. C., Macedo E. M., Kamimura, E. S., \& Trindade, M. A. (2012). Evaluation of physicochemical and sensory properties of sausages made with washed and unwashed mince from Nile tilapia by-products. $\begin{array}{lllll}\text { Journal of Aquatic Food Product Technology, 21(3), 22-237. } & \end{array}$ http://dx.doi.org/10.1080/10498850.2011.590270

Parvathy, U. Jibina, M. M., \& Sajan G. (2014). Effect of cryoprotectants on the frozen storage stability of mince and quality of mince-based products from Nemipterus japonicus (Bloch, 1791). Fishery Technology, 51, 47-53.

Pivarnik, L. F., Faustman, C., Suman, P. S., Palmer, C., Richard, N. L., P. Christopher Ellis, P. C., \& DiLiberti, M. (2013). Quality Assessment of commercially processed carbon monoxide-treated tilapia fillets. Journal of Food Science, 78(6), S902-S910. http://dx.doi.org/10.1111/1750-3841.12145

Sallam, K. I. (2007). Antimicrobial and antioxidant effects of sodium acetate, sodium lactate and sodium citrate in refrigerated sliced salmon. Food Control, 18(5), 566-575. http://dx.doi.org/10.1016/j.foodcont.2006.02.002.

Satya, S. D..2 \& Krushna, C. D. (2011). Suitability of chitosan as cryoprotectant on croaker fish (Johnius gangeticus) surimi during frozen storage. Journal of Food Science and Technology, 48(6), 699-705. http://dx.doi.org/10.1007/s13197-010-0197-8.

Sanjuás-Rey, M.,Gallardo, J. M., Barros, J., \& Aubourg, P. (2012). Microbial activity inhibition in chilled mackerel (Scomber scombrus) by employment of an organic acid-icing system. Journal of Food Science, 77(5), 264-269. http://dx.doi.org/10.1111/j.1750-3841.2012.02672.x

Sanjuás-Rey, M., García-Soto, B., Barros-Velázquez, J., Fuertes-Gamundi, J. R., \& Aubourg, S. P. (2011). Effect of a two-step natural organic acid treatment on microbial activity and lipid damage during blue whiting (Micromesistius poutassou) chilling. International Journal of Food Science and Technology, 46, 1021-1030. http://dx.doi.org/10.1111/j.1365-2621.2011.02565.x

Shaviklo, A. R., \& Rafipour F. (2013). Surimi and surimi seafood from whole ungutted myctophid mince. LWT-Food Science and Technology, 54(2), 463-468. http://dx.doi.org/10.1016/j.lwt.2013.06.019

Suvanich, V., Marshall, D. J., \& Jahncke, M.L. (2000). Microbiological and color quality changes of channel catfish frame mince during chilled and frozen storage. Journal of Food Science, 61(1), 151-154. http://dx.doi.org/10.1111/j.1365-2621.2000.tb15971.x/pdf

Thiansilakul, Y., Benjakul, S., Park, S. Y., \& Richards M. P. (2012). Characteristics of myoglobin and haemoglobin-mediated lipid oxidation in washed mince from bighead carp (Hypophthalmichthys nobilis). Food Chemistry, 132, 892-900. http://dx.doi.org/10.1016/j.foodchem.2011.11.060

Woyewoda, A. D., Shaw, S. J., Ke, P. J., \& Burns B. G. (1986). Recommended Laboratory Methods for Assessment of Fish Quality. Canadian Technical Report of Fisheries and Aquatic Sciences No. 1448.

Yarnpakdee, S., Benjakul, S., \& Kristinsson, H. G. (2012). Effect of pretreatments on chemical compositions of mince from a Nile tilapia (Oreochromis niloticus) and fishy odor development in protein hydrolysate. International Aquatic Research, 4(7), 1-16. http://dx.doi.org/10.1186/2008-6970-4-7

Yongsawatdigul, J., Pivisan, S., Wongngam, W., \& Benjakul, S. (2013). Gelation characteristics of mince and washed mince from small-scale mud carp and common carp. Journal of Aquatic Food Product Technology, 22(5), 460-473. http://dx.doi.org/10.1080/10498850.2012.664251

\section{Copyrights}

Copyright for this article is retained by the author(s), with first publication rights granted to the journal.

This is an open-access article distributed under the terms and conditions of the Creative Commons Attribution license (http://creativecommons.org/licenses/by/4.0/). 